\title{
EESTI ÜHISKONNA POLIITILISED HOIAKUD MURRANGUAASTATEL 1932-1934
}

\author{
Mark Gortfelder, Jaak Valge
}

1930. aastate alguse majanduskriis on 20. sajandi üks olulisemaid murdekohti, mis raamistas edasised majanduslikud ja poliitilised protsessid kogu maailmas. Euroopa riikide sisepoliitikas süvenes suund autoritaarsusele. Kriisi lõpul kaotas demokraatia neli riiki: Saksamaa, Austria, Eesti ja Läti. Seega võib suure majanduskriisi aega käsitleda ka Euroopa demokraatia kriisina.

Eesti demokraatia kriisi on käsitletud peamiselt poliitilise eliidi otsuste vaatevinklist. Vähem on vaadeldud ühiskonna enamuse hoiakute muutumist, ehkki demokraatia kaotuse eelduseks on ka kodanike toetuse puudumine demokraatiat eelistavatele poliitilistele jõududele. Need protsessid ja neist tõukuvad küsimused on 21. sajandi teisel kümnendil taas aktuaalsed.

Eestis toimus 1932. aasta maist kuni 1933. aasta oktoobrini kolm rahvahääletust ja parlamendivalimised, lisaks kohalikud valimised 1934. aasta jaanuaris. Nii on Eesti hea analüüsiobjekt kriisiaegsete hoiakute kujunemise uurimiseks.

\section{Tagapõhi}

Poliitilise kriisi taustaks ja peapõhjuseks oli majanduskriis. Poliitikateadlased on üksmeelel, et majanduskriis on demokraatia stabiilsusele üheks kõige suuremaks ohuks. ${ }^{1}$ Saksamaa ja Austria majandusraskused olid 1930. aastate algul ilmselt Euroopa suurimad. Eesti sisemajanduse kogutoodangu (SKT) per capita langus ei olnud sedavõrd suur, ent tulenevalt erinevast majandusstruktuurist ei kajasta SKT kriisiraskusi võrreldavalt.

1930. aastate algul sai ligi 60 protsenti Eesti elanikest oma peasissetuleku põllumajandusest. Kuna aastad 1929-30 olid põllumajanduses soodsad, jõudis kriis Eestisse toodangunäitajate alusel arvestatuna alles 1931.

1 Adam Przeworski, Michael Alvarez, José Antonio Cheibub, Fernando Limongi, "Millest sõltub demokraatia elukestus", Akadeemia, 1 (2005), 152. 
aastal. ${ }^{2}$ Kuid 1932. aastaks kukkusid põllumajandussaaduste hinnad eelkõige maailmaturu hindade languse tõttu 45 protsendini 1929. aasta tasemest, samal ajal kui kaupade hinnad, mida talud vajasid tootmisprotsessis, alanesid märksa vähem. ${ }^{3}$

Nii kujuneski siinse kriisi peamiseks põhjuseks esmajoones põllumajandus- ja metsasaadustest koosneva ekspordi langus. Ekspordi maht vähenes 1932. aastal 1929. aastaga võrreldes 22 protsenti, kuid veel enam 74 protsenti - vähenes ekspordi väärtus. ${ }^{4}$ Agraarsektori järsu ostuvõime kukkumise tõttu langes nüüd kogu majandusaktiivsus. 1929. aastaga võrreldes kahanes töötundide arv suur- ja kesktööstuses 26 protsendini. 1932. aastal registreeriti kuus keskmiselt üle 10 ooo töötu, 1933. aastal tõusis see arv 25 0oo-ni. ${ }^{5}$ Kõige raskem aeg oli 1932.- 33 . aasta talv ja kevad. Maksude alalaekumise tõttu tekkisid riigil tõsised eelarveprobleemid. Seetõttu oldi sunnitud kulud äärmuseni kokku suruma. Siiski lõppesid 1931/32 ja 1932/33 riigieelarveaastad puudujäägiga. ${ }^{6}$

Kriisiraskuste leevendamise üheks olulisemaks võtmeks oli Eesti krooni devalveerimine. Paraku jäi devalveerimise küsimus venima. ${ }^{7}$ Kahe valitsuse lagunemise otseseks põhjuseks olid lahkhelid krooni kursi küsimuses. See küsimus lõhestas ka $\mathrm{V}$ riigikogu valimiste eel tekkinud suurerakonnad.

Majandusraskuste kõrval oli paljude Euroopa demokraatlike ühiskondade rahulolematuse põhjuseks just sagedane valitsuste vahetus ja sellest tulenev tegelik või ettekujutatav alajuhtimine. Austrias ja Saksamaal oli aastatel 1919-33 valitsuste keskmine eluiga vastavalt 10 ja 9 kuud, Eestis 8 kuud. Kuid olukord halvenes veelgi just aastatel 1932-33, mil Eestis oli võimul kuus valitsust. ${ }^{8}$

Kuid erinevalt Saksamaast ja Austriast oli Eestis olemas selgem lahendus täitevvõimu ebastabiilsuse ületamiseks. Suur osa ühiskonnast seostas valitsuste ebapüsivust põhiseaduse puudustega.

\footnotetext{
2 Jaak Valge, "Uue majanduse lätteil: Eesti sisemajanduse kogutoodang aastatel 1923-1938", Akadeemia, 12 (2003), 2718-2721; Martin Klesment, "Eesti majandusarengu dünaamika näitajaid sõdadevahelisel perioodil", Tuna, 1 (2007), 29-30.

3 Arvutusalus: Eesti arvudes 1920-1935 (Tallinn: Riigi Statistika Keskbüroo, 1937), 230.

4 Arvutusalus: "Eesti majanduslik areng iseseisvuse kestel", Konjunktuur, 1/2 (1938), 26. Mahuindeks näitab abstraktset koguse liikumist ja on saadud arvestades aastati kaupu ühe ja sama (keskmise) hinnaga.

5 Eesti arvudes, 240; Juhan Janusson jt, Eesti majandus ja selle areng Eesti iseseisvuse aastail (Tartu: Eesti Kirjanduse Selts, 1937), 17.

6 Arvutusalus: Eesti arvudes, 194-195.

7 Jaak Valge, "Okkaline devalveerimine", Akadeemia, 6 (1996), 1905-1939.

8 Tiit Liblik, Euroopa demokraatlike riikide kokkuvarisemise põhjuseid kahe maailmasõja vahel, bakalaureusetöö, juhendaja dotsent Jaak Valge (Tartu Ülikooli ajaloo ja arheoloogia instituut, 2017), 38 .
} 


\section{Põhiseaduse muntmise küsimus ja rahvahääletused}

Juba enne majanduskriisi oli osa poliitilisi erakondi arusaamal, et 1920. aasta põhiseadus on teinud täitevvõimu liiga nõrgaks, pärssides nii riigi valitsemist. ${ }^{9}$ Tõsisemalt asuti teemaga tegelema 1929. aastal valitud IV riigikogus. Valimiskampaanias pooldasid põhjalikku põhiseaduse muutmist täitevvõimu tugevdamise suunas Põllumeeste Kogud (kelle toetajaskond IV riigikogu valimistel moodustas $23,1 \%$ hääletanutest ning kes olid 10o-liikmelisse parlamenti saanud 24 kohta) ja Rahvaerakond (8,9\% ning 9 kohta). Ka Tööerakonna (10,2\% ja 10 kohta) programmis nõuti põhiseaduse muutmist, kuid kokkuhoiu, mitte riigivalitsemise reformimise eesmärgil. ${ }^{10}$ Kristliku Rahvaerakonna (4,1\% ja 4 kohta) ning Asunike Koondise (13,7\% ja 14 kohta) valimispropagandas ei olnud põhiseaduse muutmine olulisel kohal ja ka väikeparteid - Majaomanike Liit (2,9\% ja 3 kohta), Saksa-Rootsi valimisblokk (3,2\% ja 3 kohta) ja Vene Rahvuslik Liit (2,5\% ja 2 kohta) ei näinud põhiseaduse muutmiseks suurt vajadust. Üheselt põhiseaduse muutmise vastu olid aga sotsialistid (24\% ja 25 kohta). ${ }^{11}$ Kõikidele reformidele olid vastu kommunistlike eelistustega valijad, keda IV riigikogus esindas Eesti Tööliste Partei (6,2\% ja 6 kohta). Nii said IV riigikogu valimistel põhjalikku muutusi soovijad kokku 32 protsenti häältest ja 33 kohta, kindlad vastased aga 30,2 protsenti ja 31 kohta, (pigem) neutraalsel seisukohal olijad aga 37,8 protsenti häältest ning 36 kohta. $^{12}$

Sellise toetuse jaotusega läks põhiseaduse muutmise küsimuse arutamine ja menetlemine Toompeal aeglaselt. Kuid 1931. aastal ilmus Eesti poliitilisele eeslavale uus, parlamendiväline jõud - vabadussõjalaste liikumine, kellelt Konstantin Päts ja Jaan Tõnisson soovisid toetust põhiseadusreformi läbiviimiseks. ${ }^{13}$ Vabadussõjalaste peamiseks nõudmiseks kujuneski põhiseaduse muutmine, et seada ametisse otsevalitav riigipea ja stabiliseerida täitevvõim. Nende populaarsus, nagu ka toetus põhiseaduse muutmisele, suurenes 1932.-33. aastal järsult.

\footnotetext{
9 Põhiseaduse muutmise küsimusest pikemalt: Jaak Valge, “Tee teise rahvahääletuseni 1932. aastal", Tuna, 2 (2017), 20-36.

10 Mida tahab Tööerakond? Tööerakonna eeskava ja põhimõtted (Tallinn: Tööerakonna Keskkomitee, 1929), 6; Kodanik otsustagu (Tallinn: Tööerakonna Keskkomitee, 1929).

11 Kelle poolt hääletab töölisklass? (Tallinn: Eesti Sotsialistlik Tööliste Partei, 1929).

12 IV Riigikogu valimised 11.-13.maini 1929 (Tallinn: Riigi Statistika Keskbüroo, 1929), 11.

13 Eduard Laaman, "Põhiseaduse kriisi arenemine 1928-1933", Põhiseadus ja Rahvuskogu (Tallinn: Rahvuskogu, 1937), 38; Hiljem, 17. augustil 1932 tunnistas Päts eravestluses vabadussõjalaste rolli põhiseaduse küsimusega taganttorkimisel: "Alles kui need oma tähtajaga esinesid, saavutasid rühmad kokkuleppe", vt "Meie vastus: Eduard Laamani päevik 1922-1940", Akadeemia, 12 (2003), 2761.
} 
Eesti Vabariigi põhiseadust sai muuta vaid rahvahääletusega. Referendumi võis käivitada riigikogu oma häälteenamusega, aga ka rahvaalgatuse korras vähemalt 25 ooo kodaniku nõudmisel. Rahvahääletuse tulemus oli siduv. Rahvahääletuse kord ja alused olid määratud seaduses, mille kohaselt pidi põhiseaduse muutmine loetama rahvahääletusel vastuvõetuks, kui selle poolt hääletas vähemalt pool kõigist hääleõiguslikest kodanikest. ${ }^{14}$

Põhiseaduse muutmist soodustas agraarerakondade (Põllumeeste Kogud ja Asunike Koondis), ja keskerakondade (Rahvaerakond, Tööerakond, Kristlik Rahvaerakond ning Majaomanike Liit) liitumine enne V riigikogu valimisi. Mõlemas suurparteis - ühinenud põllumeeste erakonnas ja Rahvuslikus Keskerakonnas - said juhtohjad enda kätte varem põhiseaduse muutmist toetanud erakonnad. IV riigikogu lõpus oli neil kokku 64 kohta. Ent nagu näitavad sõnavõtud ja hääletused, polnud parteiline distsipliin selles küsimuses alati toimiv. Siiski suudeti 1932. aasta märtsi lõpus põhiseaduse muutmise kava vastu võtta. Eelnõu nägi ette otsevalitava presidendi ametikoha ning riigikogu liikmete arvu vähendamist 8o-ni. Kuid enne rahvahääletust toimusid veel ühed valimised.

V riigikogu valimistel mais 1932 toetas Rahvuslikku Keskerakonda 22,1 protsenti (23 kohta) ja ühinenud põllumehi 39,8 protsenti (42 kohta) valijaist, samas kui sotsialiste toetas 20,9 ja kommunistliku hoiakuga pahempoolsete tööliste ja kehvikute nimekirja 5,2 protsenti. Ülejäänud künnise ületanud nimekirjadel - Vene ja Saksa-Rootsi valimisblokkidel - oli 12 protsendi valijate toetus ja 8 kohta riigikogus. ${ }^{15}$ Uus riigikogu muutis ka rahvahääletuse seadust, nii et põhiseaduse muutmine pidi loetama vastuvõetuks, kui selle poolt oli rahvahääletusest osavõtjate enamus. Teisalt aga seati sisse rahvahääletusel osalemine kohustus, ilma vabandatava põhjuseta mitteosalemine tähendas rahatrahvi. ${ }^{16} \mathrm{Nii}$ tundus muutmine olevat otsustatud.

Esimene põhiseaduse muutmise teemal peetud rahvahääletus toimus 13.-15. augustil 1932. Põhiseaduse muutmiskava vastupropagandat tegid vabadussõjalased ja sotsialistid. Esimeste arvates oli riigipeal uue kava järgi liiga vähe võimu, parlamendisaadikute arv liiga suur ning läbi polnud viidud isikuvalimiste põhimõtet, sotside arvates tähendas täitevvõimu tugevdamine demokraatia ja töölisklassi nõrgendamist. Kommunistid, nagu eelpool mainitud, olid samuti reformide vastu. Põhiseaduse muutmist toetav

14 Riigi Teataja, 16 (1926), 145.

15 VRiigikogu valimised 21.-23. maini 1932 (Tallinn: Riigi Statistika Keskbüroo, 1932), 51.

16 Riigi Teataja, 16 (1926), 145. 
propaganda oli aga ebaühtlane ja loid. ${ }^{17}$ Riigikogu ettepanek sai napi kaotuse osaliseks: seda pooldas 49,2 protsenti hääletamas käinutest.

Pärast eelnõu läbikukkumist toimusid vabadussõjalaste poolt pinnasondeerimised uue ühise eelnõu koostamiseks, ent need lõppesid edutult. 9. novembril 1932 esitasid vabadussõjalased oma eelnõu rahvaalgatuse korras riigikogu juhatusele. ${ }^{18}$ Vabadussõjalaste eelnõu oli koostatud varasemate projektide alusel. Kodanike põhiõigustes muudatusi ette ei nähtud. Riigikogu pidi olema 50-liikmeline. Riigipea oli otsevalitav ega saanud muuta rahvahääletamise, rahvaalgatamise, riigikogu valimise ega riigivanema valimise seadust. Riigipea ei saanud põhiseaduse muutmiseks isegi ettepanekut teha, rääkimata selle muutmisest. Kuid riigivanem võis riigikogu laiali saata ning pidi määrama kuue kuu jooksul toimuvad valimised. ${ }^{19}$

Erakondade juhtpoliitikud otsustasid 25. novembril vabadussõjalasi ennetada ning algatada teise põhiseaduse muutmise eelnõu koostamise. ${ }^{20}$ Kui riigikogu soovis neist ette jõuda, pidi ta oma eelnõu valmis saama ja rahvahääletusele saatma 2-3 kuu jooksul. Riigikogu täiskogu alustas põhiseaduse kava arutamist jaanuaris. ${ }^{21}$ Samal kuul hakati põhiseaduse komisjonis arutama ka rahvahääletuse korra muutmist.

Nüüdses riigikogu eelnõus oli parlamendiliikmeid 100 (mitte 8o, nagu eelmises) ning nad pidi valitama proportsionaalsuse põhimõtte alusel, kuid uues eelnõus oli lisatud "nõnda, et valijal oleks võimalik valida isikuid". Riigipea võis riigikogu laiali saata, aga pidi määrama, et erakorralised valimised toimuvad hiljemalt kolme kuu jooksul (eelmises eelnõus kaks kuud). Riigikogu liikmetele võis uue eelnõu kohaselt tasu maksta kuni kuue kuu eest, 1932. aasta eelnõus ei olnud aeg piiratud. Kaotatud oli säte, mille kohaselt pidi riigikogu laiali minema, kui rahvahääletuse tulemus on vastuolus riigikogu hääletustulemusega. ${ }^{22}$

Nädal hiljem, 21. veebruaril, võttis riigikogu vastu rahvahääletuse muutmise seaduse, millega tühistas taas hääletamiskohustuse ja hõlbustas

\footnotetext{
17 Imre Lipping, “The Emergence of Estonian Authoritarianism”, Baltic History, ed. by Arvids Ziedonis, William L. Winter, Mardi Valgemäe (Columbus: Association for the Advancement of Baltic Studies, 1974), 211.

18 Rahvusarhiiv (edaspidi RA), ERA.80.5.2038: Seiman, Tõnson, Sirk ja Rõuk riigikogu juhatusele 9.11.1932.

19 Eerik-Juhan Truuväli märgib, et hinnangud 1933. aasta põhiseadusele on olnud negatiivsed, mis paljugi johtuvad sellest, et eelnõu lähtus vabadussõjalastelt, vt EerikJuhan Truuväli, Põhiseaduse teel (Tallinn: Ilo, 2008), 136.

20 Riigikogu V koosseis: täielikud protokollid (Tallinn: Täht, 1933), 2. ij, 385-386.

${ }^{21}$ V Riigikogu, 2. ij, 437-478.

22 1932. aasta eelnõu: Riigikogu IV koosseis: täielikud protokollid (Tallinn: Ühiselu, 1932), 9.ij, lisad, 763-766; 1933. aasta eelnõu: V Riigikogu, 2. ij., 48-52.
} 
eelnõu vastuvõtmist: nüüd oli selleks vajalik hääletamisest osavõtnute poolthäälte enamus, mis pidi moodustama vähemalt 30 protsenti hääleõiguslike arvust. ${ }^{23} 22$. veebruaril kuulutas riigikogu juhatus seaduse välja ja otsustas määrata riigikogu põhiseaduse kava rahvahääletamise 10., 11. ja 12. juuniks $1933 .{ }^{24}$ Kuus päeva hiljem sai täis seadusega ettenähtud allkirjade kogumise aeg vabadussõjalaste kavale.

Vabadussõjalaste propaganda ründas eelnõud teravalt ja agressiivselt. Sotsialistide propaganda kritiseeris eelnõud sedapuhku vaoshoitumalt, suunates oma rünnaku vabadussõjalaste vastu. Samas pingutasid varasemast rohkem kihutustööga eelnõud toetajad, eriti Rahvuslik Keskerakond. Nüüd sai riigikogu ettepanek selge kaotuse - poolthääle andsid kõigest 32,7 protsenti hääletamas käinutest.

Edasi kaaluti poliitringkondades küsimust, kas eelnõu tagasilükkamine tähendab umbusaldust valitsusele, parlamendile või mõlemale. Riigikogu juhatuse vastus oli parlamendi osas eitav. ${ }^{25}$

Kuna riigikogu eelnõu oli läbi kukkunud, siis oli kord vabadussõjalaste eelnõu käes, mille üle määrati rahvahääletus toimuma 14.-16. oktoobrile. ${ }^{26}$ Poliitiline olukord pingestus. 18. juunil lõhenes ühinenud põllumeeste erakond taas Põllumeeste Kogude erakonnaks ja endiseks asunike erakonnaks. 27.-28. juunil viis Jaan Tõnissoni valitsus läbi krooni devalveerimise, mis tõi kaasa vastaste tulise protesti. 11. augustil kuulutas valitsus sotsialistide survel välja kaitseseisukorra kogu riigis, millega piirati sõnavabadust. Tsensuuri sisseseadmine tõi kaasa ajakirjanduse üldise pahameele. Mitu suuremat ajalehte ei avaldanud enam uudised valitsuse tegevuse kohta. Kuid vabadussõjalaste põhiseaduse muutmise ettepaneku osas ei olnud diskussioon pärsitud.

4. oktoobril võttis riigikogu vastu seaduse, millega raskendati põhiseaduse muutmist: see pidi loetama vastuvõetuks siis, kui selle poolt oli hääletanud vähemalt pool kõigist hääleõiguslikest kodanikest ehk sisuliselt naasti enne põhiseaduse referendumeid kehtinud korra juurde. ${ }^{27}$ Seadus poolt hääletasid kõik kohalolnud sotsialistid, kommunistid, venelased, keskerakonna enamus ning asunike fraktsiooni enamus - kokku 47 häält, vastu olid kõik Põllumeeste Kogude saadikud ning osa keskerakonna ja

\footnotetext{
$23 \quad$ V Rigikogu, 2. ij., 547-559; Riigi Teataja, 19 (1933), 182.

24 RA, ERA.80.5.282, l. 64: V Riigikogu juhatuse protokoll, 22.02.1933.

25 RA, ERA.80.5.1692, 1. 1: Rahvuslik Keskerakond Riigikogu juhatusele, 13.06.1933.

26 RA, ERA.80.5.282, 1. 104: Riigikogu juhatuse protokoll, 29.06.1933.

27 Riigikogu V koosseis: täielikud protokollid (Tallinn: Täht, 1934), 3. ja 4. ij., 90o-903.
} 
asunike saadikutest - kokku 29 häält. ${ }^{28} \mathrm{Nii}$ oli riigikogu enamus end hääletamisele tulevale eelnõule vastandanud.

Vabadussõjalaste ettepanekut asusid kohe toetama Põllumeeste Kogud. ${ }^{29}$ Mitmes erakonnas valitsesid erimeelsused. Mõjukas Põllumeeste Kogude poliitik Jaan Teemant asus eelnõule oponeerima ja asunike erakonna juhtkond, kes oli esialgu selgelt vabadussõjalaste eelnõu vastu, jättis viimasel hetkel oma liikmetele õiguse vabalt otsustada ning selle üks tiib asuski seda toetama. ${ }^{30}$ Ajalehtedest oli eelnõu poolt Põllumeeste Kogude häälekandja Kaja, pigem vastu linnakodanluse vaadet kajastav Päevaleht ning selgelt vastu Rahvaerakonna Postimees. Raevukalt agiteerisid vastu sotsialistid, ent ei propageerinud hääletamise boikoteerimist, mis võinuks samuti eelnõu tagasilükkamisele viia.

14.-16. oktoobril toimunud kolmandal põhiseaduse muutmise küsimuses peetud rahvahääletusel arvestati hääleõiguslikke kodanikke 763073 . Seega oli eelnõu heakskiitmiseks vajalik 381537 kodaniku poolthäält. Eelnõu sai 416878 poolt- ja 156894 vastuhäält.

\section{Historiograafia}

Eesti autoritaarvõimu üks peaideolooge Eduard Laaman seostab poolehoidu põhiseaduse muutmisele majanduskriisiga ja põhjendab vabadussõjalaste populaarsust osalt keskkihtide vaesumisega, osalt aga sõja psühholoogiliste järelmõjudega, kuid tõstab esile, et viimasel rahvahääletusel poolthääletajad polnud kõik vabadussõjalaste poolehoidjad. ${ }^{31}$ Sarnast vaadet esindab ka autoritaaraja teine ideoloog Johannes Klesment, kes toonitab samuti, et pole põhjust arvata, et kolmanda põhiseaduse eelnõu poolt hääletanud enamus oleks jaganud "vabadussõjalaste autoritaarse režiimi poole sihitud vaatekohti". Ta leiab siiski, et riigikogu kaotas oma maine. ${ }^{32}$

Esimese ajalise distantsiga analüüsi sellest, mis toimus neil kahel murranguaastal erakondade poolehoiuga Eestis, koostas õigusteadlane ja autoritaaraja tippametnik Artur Mägi. Ta püstitas uurimisküsimuse: missuguste erakondade valijate häältega otsustati põhiseaduse muutmise küsimus ja missugused erakonnad säilitasid oma valijaskonna usalduse

\footnotetext{
28 "Kvoorumiseadus võeti 3. lugemisel vastu", Võitlus, 7.10.1933.

29 "8. üleriiklise põllumeeste kongressi otsused", Kaja, 20.06.1933.

30 Rein Marandi, Must-valge lipu all: vabadussõjalaste liikumine Eestis 1929-1937, I: legaalne periood (1929-1934) (Stockholm: Stockholmi Ülikool, 1991), 229, 236-237.

31 Laaman, "Põhiseaduse kriisi arenemine 1928-1933", 35, 44.

32 Johannes Klesment. "Sisepoliitiline kriis ja põhiseadus”, Põhiseadus ja Rahvuskogu (Tallinn: Rahvuskogu, 1937), 54.
} 
senise riikliku korra rakendajana? ${ }^{33}$ Mägi on võtnud oma analüüsi aluseks 1929. ja 1932. aasta parlamendivalimiste tulemused ning liigitanud erakonnad põhiseaduse muutmise pooldajateks (mitte-marksistid) ja vastasteks (marksistid).

Mägi väidab, et põhiseadust muuta soovivatele ehk kodanlikele erakondadele anti 1929. aasta parlamendivalimistel 68,6 ja 1932. aasta parlamendivalimistel 72,8 protsenti häältest. Sama aasta augustis toimunud rahvahääletusel hääletas riigikogu ettepaneku poolt vaid 48,2 protsenti. Seega - järeldab Mägi - isegi kui oletada, et kogu marksistlike erakondade valijaskond hääletas eranditult riigikogu ettepaneku vastu, siis järelikult 24,6 protsenti hääletanutest oli seekord oma poliitilise juhtkonna seisukoha vastu või jäänud erapooletuks. "Arvestades vabadussõjalaste poliitilisi eesmärke oli oodata tõsiseid sisepoliitilisi raskusi." ${ }^{34}$

Samasugust loogikat kasutades analüüsib Mägi ka järgnevaid rahvahääletusi. Arvutuste tulemusena järeldab Mägi, et erakonnad, kes olid aktiivselt vastu vabadussõjalaste kavale, käsutasid veel ainult pisut enam kui kolmandikku oma senisest valijaskonnast. Suhtelises paremas olukorras oli tema arvates väliselt Põllumeeste Kogude erakond. See ei võimalda aga tema arvates veel järeldada, et Põllumeeste Kogude valijaskond oleks senistele juhtidele järgnenud ka siis, kui need oleksid andnud oma valijaskonnale käsu hääletada vabadussõjalaste põhiseaduse muutmise seaduse vastu. Mägi viitab ka 1934. aasta alguses toimunud kohalike omavalitsuste valimistele, mille tulemused kinnitasid tema arvates erakondade usalduse kaotust. ${ }^{35}$

Kuna marksistiks mitteolemine ei tähendanud põhiseaduse muutmise toetamist, siis on tema liigitus ja sellest johtuvalt ka analüüs ebapiisav. Mäe eeldus rahvahääletuse tulemustest kui tõestusest, et erakonnad olid kaotanud oma valijaskonna usalduse ja libisemas vabadussõjalaste mõju piirkonda, põhineb eeldusel, et vabadussõjalaste suuniste kohaselt häletamine referendumitel tähendas oma parlamendivalimistel eelistatud erakondade täielikku hülgamist, poliitilist maalibisemist. Tema hinnangud vabadussõjalastele on samuti ülikriitilised. Seega võiks arvata, et Mägi üritab lugejat veenda, et kujunenud olukorras oli parimaks lahenduseks riigipööre.

Rein Taagepera leiab, et Baltimaade rahvastel oli 1930. aastate alguses kolm valikut: vaevaline demokraatia, tõusuteel Lääne autoritaarsus

\footnotetext{
33 Artur Mägi. “Rahvaalgatus ja rahvahääletus Eestis”, Omariikluse taustal (Uppsala: ÜS Raimla, 1955), 33.

34 Ibid., 28.

35 Ibid., 33; 36-40.
} 
ja bolševism. Ta kinnitab ilma oma teesi tõestamata, et pole imestada, et need bolševismi tõrjunud ja sügava kodanikukultuurita rahvad järgisid Lääne autoritaarset mudelit. ${ }^{36}$

Hoopis põhjalikumalt on teemat käsitlenud Tõnu Parming, kes opereerib esimese ja kolmanda põhiseaduse rahvahääletuse tulemustega ja on astunud oma analüüsis suure sammu Mäest edasi. Parming toob välja, et tema käsitletud kahe referendumi erinev tulemus on seotud eelkõige linnaja alevielanike hoiakutega, sest maal oli toetus absoluutarvudes sisuliselt sama. Ta sõnastab võtmeküsimuse: missuguses linnaelanikkonna segmendis toimus muutus? ${ }^{37}$

Parming kasutab oma analüüsis ka statistilisi meetodeid. Tema tulemused näitavad väga tugevat seost kodanlike erakondade häälte osakaalu ja vabadussõjalaste ettepaneku toetamise vahel linnades ja alevites. Parming järeldab, et oma senistes esindajates pettusid just linnade keskkihid, kes ei toetanud riigikogu eelnõusid ning nendest saigi vabadussõjalaste peamine toetajagrupp, kuid tunnistab ka töölisklassi sümpaatiat vabadussõjalaste suhtes. Päevalehte tsiteerides väidab Parming, et oma lähenemise struktuurilt olid vabadussõjalased ühtlasi natsionaalsotsialistlik ja fašistlik partei, kus sotsialistlikel elementidel oli tähtis kaal, ning jätkab, et see selgitab, mis osa linnavalijatest, kes olid traditsiooniliselt toetanud vasakpoolsust, lülitusid ümber vabadussõjalastele 1934. aasta kohalikel valimistel ja võimalik, et ka 1933. aasta oktoobris toimunud referendumil..$^{38} \mathrm{Maa}$ keskklass, vastupidi, ei toetanud vabadussõjalaste kandidaate 1934. aasta kohalikel valimistel. Isegi kui maa keskklass toetas uut tugeva täitevvõimuga konstitutsiooni 1933. aasta oktoobris, toetas ta 1934. aasta kohalikel valimistel traditsioonilisi konservatiivseid agraarkandidaate. ${ }^{39}$

Kokkuvõttes analüüsib Parming tulemusi, ning leiab, et demokraatlikud parteid ei mõistnud, et nemad ise olid ebastabiilsuse kui peamise poliitilise probleemi põhjustajad. Nad ei olnud valmis lahendama neid küsimusi, mis olid lahendatavad, luues nii poliitilise vaakumi, mida asusid täitma vabadussõjalased. ${ }^{40}$ Paljud Parmingu eeldused ja väited ei ole hästi tõendatud. Metodoloogiliselt ebaõige on tema otsus eemaldada analüüsist kolm linna (Haapsalu, Tapa, Põltsamaa) ja kolm alevit (Kärdla, Mustvee,

\footnotetext{
36 Rein Taagepera, "Civic culture and authoritarianism in the Baltic States, 1930-1940", East European Quarterly, 4 (1974), 408.

37 Tõnu Parming, The collapse of liberal democracy and the rise of authoritarianism in Estonia (London: Sage Publications, 1975), 50-51.

38 Parming, The collapse of liberal, 53-55.

39 Ibid., 56.

40 Ibid., 65.
} 
Kallaste), mis võiksid ta järeldusi muuta. Kuid hoolimata küsitavustest on Parmingu analüüs jäänud senini mitte ainult kõige põhjalikumaks, vaid ka kõige paremini argumenteeritumaks.

Hiljem põhjalikumaid analüüse tehtud ei ole. Nõukogude Eestis tegutsenud ajaloolastest on teemat kõige põhjalikumalt käsitlenud Olaf Kuuli, kes peab juba esimest põhiseaduse rahvahääletust fašistliku diktatuuri ettevalmistavaks sammuks, mille vastu astus aktiivselt vaid Eestimaa Kommunistlik Partei. Ta pakub, et tõenäoliselt hääletasid esimesel põhiseaduse rahvahääletusel vastu peaaegu kõik V riigikogu valimistel ESTP ning pahempoolsete tööliste ja kehvikute valijad, st 26,2 protsenti, ning sel juhul võib vabadussõjalaste pooldajate arvuks hinnata 150 ooo-160 ooo. Teise rahvahääletuse tulemustes näeb Kuuli aga "vastuolude kasvamist kodanliku valitsuse ja rahvahulkade vahel ning lahkhelide teravnemist ka kodanlike rühmituste endi vahel". Kolmanda rahvahääletuse puhul märgib Kuuli aga, et Rahvusliku Keskerakonna ja ESTP mõju oli tugevalt vähenenud ja paljud nende erakondade pooldajad olid üle läinud vapside leeri. ${ }^{41}$

Andres Kasekamp on Parmingu analüüsile oponeerinud, pidades ebaõigeks hinnangut, et just keskerakondade valijad ehk linna keskkihid pöörasid selja oma endistele esindajatele. Ta viitab 1934. aasta kohalikele valimistele, kaasaegsete hinnangutele ning vabadussõjalaste liikmete ja kandidaatide nimekirjadele, mis tõestavad nende laiapõhjalist sotsiaalset toetust, sealhulgas ka lihttööliste ja kõrgemate kihtide hulgas. ${ }^{42}$

Toomas Varrak leiab, et vabadussõjalaste edu üks olulisi põhjusi oli asjaolu, et just linnade töötud, kes 1930. aastal olid olnud sotsialistide toetajad ning aastatel 1931-33 hoidsid kommunistide poole, sattusid 1933. aasta lõpuks vabadussõjalaste mõju alla. ${ }^{43}$ Tegelikult oli töötuid üldisest valijaskonnast siiski vähe, pealegi oli 1933. aasta lõpuks tööpuudus juba vähenenud ning kommunistide vahepealset mõju suurenemist töötute seas ei kinnita 1930. aasta valimistulemuste võrdlus 1932. aastaga: viimastel valimistel said kommunistid ühe koha vähem.

${ }^{41}$ Olaf Kuuli, Vapsidest Isamaaliiduni (Tallinn: Eesti Raamat, 1976), 77, 87-90. Nõukogude Eesti ajaloo üldkäsitlustes väidetakse, et vabadussõjalaste põhilise toetajaskonna, kes ka rahvahääletusel nende poolt hääletasid, moodustasid linna väikekodanlikud kihid, aga ka teatud osa proletariaadist, eriti töötutest (Eesti NSV ajalugu, 3. kd: 1917. aasta märtsist kuni 50-ndate aastate alguseni (Tallinn: Eesti Raamat, 1971), 309; Eesti NSV ajalugu: kõrgkoolide ópik, II osa (Tallinn: Valgus, 1980), 185).

42 Andres Kasekamp, The radical right in interwar Estonia (Basingstoke: MacMillan, 2000), 90-93.

43 Toomas Varrak, "Estonia: crises and "pre-emptive" authoritarianism", Authoritarianism and democracy in Europe, 1919-39: comparative analyses, ed. by. Dirk Berg-Schlosser and Jeremy Mitchell (Basingstoke: Palgrave Macmillan, 2002), 121. 
Ago Pajur väidab, et vabadussõjalaste poolehoidjaid leidus kõikides rahvakihtides, kuid "ennekõike oli see siiski linlaste ja noorema põlvkonna liikumine, mis vastandas end osaliselt vanemale generatsioonile ja alalhoidlikumale maarahvale. Ühtlasi koondas liikumine majanduskriisi läbi isiklikult kannatanud ja seetõttu riigis pettunud inimesi." ${ }^{\text {44 }}$

Heino Arumäe kinnitab, et vabadussõjalased lõid tõelise massiliikumise, millel oli hulgaliselt pooldajaid ühiskonna kõikides kihtides. Talurahva seas märgatavat edu siiski ei saavutatud. "Teadagi leidsid vabadussõjalased kõige enam kaasaminejaid linnarahvastiku keskkihtides - väikeettevõtjate, poodnike, ametnike jt seas, kuid üha enam toetas neid tööliskond ja isegi põhjakihid.” Arumäe kinnitab ka, et suur osa revolutsiooniliste traditsioonidega tööliskonnast Tallinnas, Narvas ja mõnes töölisalevis asus toetama vabadussõjalasi. ${ }^{45}$

Käesolevas uurimuses üritatakse hoopis laiema statistilise baasi ja kaasaegsema metoodika alusel kindlaks teha, missuguste erakondade elektoraat hääletas erinevatel referendumitel poolt ja vastu? Teiseks üritatakse eelnevate analüüside, aga lisaks ka 1934. aasta kohalike valimiste tulemuste ja riigipeade toetusallkirjade põhjal arutleda, missugune oli vabadussõjalaste tegelik toetusbaas 1934. aasta talvel ja kevadel. Kas on põhjust põhiseaduste rahvahääletuste alusel eeldada, et toetus vabadussõjalastele oli 1933. aasta lõpul ja 1934. aasta algul ülisuur?

\section{Metoodika}

Põhiseaduse muutmise toetamine (analüüsime kolme rahvahääletust eraldi) on analüüsi sõltuv tunnus (seletatav tunnus, väljund, funktsioon) (muutuja $Y$ ). Soovime teada, millised sõltumatud tunnused (seletavad tunnused, sisendid, argumendid) (muutuja $X$ ) seda mõjutavad (eelkõige on selliseks tunnuseks ühe erakonna toetus). Uurimaks analüüsitunnuste mõju põhiseaduse muutmise toetamisele, kasutame käesolevas artiklis tänapäevase sotsiaalteaduste üht levinumat kvantitatiivse andmeanalü̈si meetodit - lineaarset regressiooni. ${ }^{46}$ Lineaarsus tähendab, et huvipakkuv seos kahe muutuja vahel peab olema kirjeldatav sirgjoonega (kas tõusva või

44 Eesti ajalugu VI: Vabadussõjast taasiseseisvuseni (Tartu: Ilmamaa, 2005), 86.

45 Heino Arumäe, "1934. aasta 12. märts kaasaegsete hinnanguis", Alasi ja haamri vahel (Tallinn: MTÜ Konstantin Pätsi Muuseum, 2007), 23; 25-27.

46 Eesti keeles pikemalt: Liina-Mai Tooding, Andmete analüüs ja tõlgendamine sotsiaalteadustes (Tartu: Tartu Ülikooli Kirjastus, 2016), 245-288; tehnilisemalt: James A. Stock ja Mark S. Watson, Introduction to econometrics (Boston: Addison-Wesley, 2011), 107-251. 
langevaga), mitte aga olema U-kujuline, lainetav vms. Regressioon viitab tagasipöördumisele ja taandamisele, see tähendab, et $X$-i väärtused mõjutavad süsteemselt $Y$-i väärtuseid ehk teatud osa sõltuva tunnuse väärtuste muutlikkusest on taandatav sõltumatu tunnuse väärtuste muutlikkusele. ${ }^{47}$

Kuna põhiseaduse muutmise poolthäälte osakaal sõltub mitmetest teguritest, siis sisaldavad regressioonimudelid mitmeid seletavaid muutujaid. Nii on võimalik välja arvutada iga üksiku muutuja mõju uuritavale näitajale. Teisisõnu tekib ceteris paribus olukord, kus muid faktoreid võrdsena hoides (nende mõju kontrollides) saame teada iga üksiku sõltumatu muutuja mõju sõltuvale muutujale.

Kasutatava mudeli kuju on meie analüüsis järgmine:

$$
\text { põhiseadus }_{i}=\alpha+\beta_{1} * \text { erakond }_{i}+\beta_{2} * \text { agraarsektor }_{i}+\ldots+\epsilon
$$

Põhiseadus on mudelis põhiseaduse muutmise ettepaneku toetamise protsent omavalitsuses $i$. Vabaliiget tähistab $\alpha$ ja seda me tulemuste tõlgenduses ei kasuta. Erakond on meie tähtsaim sõltumatu muutuja, mis tähistab ühe erakonna häälte osakaalu parlamendi valimistel omavalitsuses $i$. Tunnuse kordajaks (tõusuks) on $\beta_{1}$. agraarsektor on põllumajandussektorist ülalpeetavate meessoost isikute osakaal omavalitsuses $i$. Selle kordajaks on $\beta_{2}$. Samamoodi on mudelis kõik teised meie poolt kasutatavad sõltumatud tunnused, millel kõigil on eraldi kordajad $\left(\beta_{3}, \ldots \beta_{N}\right)$. Kordaja on näitaja, mis kehastab seletava muutuja efekti seletatavale muutujale ehk meie tulemus. Kordaja näitab, mis on sõltumatu muutuja ühe ühikulise tõusu mõju sõltuvale muutujale. Mida suurem on kordaja absoluutväärtus, seda tugevam on süsteemne suhe. Kuna meie analüüsis on kõik tunnused protsendid, siis väljendab kordaja üheprotsendilise tõusu süsteemset mõju. Näiteks kordaja 0,43 tähendaks siis, et erakonna $x$ toetamise üheprotsendiline tõus kasvatab põhiseaduse muutmise toetust 0,43 protsenti. Kui kordaja on miinusmärgiga, siis tähendaks see 0,43 -protsendilist kahanemist.

Mudel võtab aluseks reaalsed (vaadeldud) väärtused ja optimeerimisülesande käigus arvutab välja hinnangulised (ennustatud) väärtused. Kuna ka kõige parem mudel ei ole võimeline täielikult kirjeldama kogu reaalse elu kirevust, siis lahknevad vaadeldud ning hinnangulised väärtused üksteisest

47 Lihtne regressioonimudel on erinev korrelatsioonist. Korrelatsioon on sümmeetriline (ehk korrelatsioon X ja Y vahel on sama, mis Y ja X vahel), kuid sõltuva ja sõltumatu tunnuse vahetus lihtsa lineaarse regressiooni jaoks sarnast efekti ei anna. Samuti ei võimalda korrelatsioon hõlmata rohkem kui kahte tunnust. 
ning optimeerimisülesande eesmärk ongi leida reaalset elu kõige paremini kirjeldav lahendus. Esitatud valemi viimane komponent $-\varepsilon-$ tähistabki jääke (hälvet või viga), mis on iga omavalitsuse reaalsete ning mudeli hinnanguliste (ennustatud) väärtuste vahel. ${ }^{48}$

Lineaarse regressiooni üks levinuimad probleeme on, et kaks või enam sõltumatut muutujat on omavahel tugevamas seoses kui on seos sõltuva muutujaga (multikollineaarsus). Nii annab mudel tulemuseks kallutatud kordajad. Antud analüüsi puhul tähendab see, et me ei saa panna ühte mudelisse mitmeid erakondlikke tunnuseid, kuna kõigi nende puhul on tegemist osadega tervikust. Seega on meie mudelites alati üks erakondlik tunnus, lisaks sotsiaalsed ja majanduslikud kontrolltunnused.

\section{Andmed ja tulemuste esitamine}

Käesoleva uurimuse analüüsiüksusteks on kohalikud omavalitsused.$^{49}$ Neid puudutavad andmed pärinevad Riigi Statistika Keskbüroo mitmesugustest publikatsioonidest. Käsitletud rahvahääletuste osalusprotsent ja tulemused on kohalike omavalitsuste kaupa ära trükitud kuukirja Eesti Statistika 1933. aasta viimases numbris. ${ }^{50}$ Andmed valimistel osaluse ning valimistulemuste kohta on võetud Statistika Keskbüroo valimiste eriväljaannetest. ${ }^{51}$

Lisaks kasutame kontrolltunnustena kohalike omavalitsuste kaupa nende elanikkonda iseloomustavaid sotsiaalseid ja majanduslikke näitajaid. Hariduslikest näitajatest kasutame kesk- ja kõrgharidusega meeste osakaalu omavalitsuses, mis pärinevad 1922. aasta rahvaloendusest. ${ }^{52}$ Sama rahvaloenduse andmetest kasutame ka mitte-eestlaste osakaalu kohalikust elanikkonnast. ${ }^{53}$

\footnotetext{
48 See prognoosijääk hõlmab endast juhuslikku varieerumist ning ka muid sõltuvat muutujat mõjutavaid faktoreid, mida mudelisse kaasatud pole. Mudeli (või õigemini tulemuste täpsuse) eeldus on, et see hälve on normaaljaotuse (sellele sarnaneva) kujuga, keskmiselt o ja püsiva hajuvusega kogu andmepiirkonnas. Teisisõnu mudeli ennustatu on ühtlaselt täpne kogu sõltuva tunnuse väärtuste piirkonnas.

49 Kokku 407 kohalikku omavalitsust.

50 A. Tooms, "Rahvahääletused põhiseaduse muutmiseks", Eesti Statistika, 12 (1933), 605-617.

51 A. Tooms, VRiigikogu valimised (Tallinn: Riigi Statistika Keskbüroo, 1932); A. Tooms, IV Riigikogu valimised (Tallinn: Riigi Statistika Keskbüroo, 1929).

52 1922. a üldrahvalugemise andmed (vihud IV-XI) (Tallinn: Riigi Statistika Keskbüroo, 1924).

53 Siinkohal avaldame tänu Veiko Berendsenile, kellelt on saadud rahvaloenduse tabuleeritud andmed.
} 
Kaks majanduslikku näitajat on saadud 1934. aasta rahvaloenduse andmetest. ${ }^{54}$ Põllumajandusest ülalpidamist saava rahvastiku osakaal näitab omavalitsuste majandusstruktuuri agraarsuse taset, aktiivsete ehk tööga iseseisvat sissetulekut teenivate inimeste osakaal koguelanikkonnast kirjeldab aga nii töötuse kui ka palgamajanduse levikut. ${ }^{55}$ Eristamaks noorte mõju on toodud analüüsi 20-24-aastaste elanike osakaal kõikidest täiskasvanutest (20-aastased ja vanemad), mis pärineb samuti 1934. aasta rahvaloendusest. ${ }^{56}$

Tulemused on esitatud rahvahääletuste kaupa kolmes alaosas. Iga alaosa algul on lühidalt kirjeldatud poolthäälte jaotust ning puudutatud hääletusaktiivsuse mõju hääletustulemustele. Seejärel on joonistel välja toodud mudelite tulemused. Mudelite tulemuste tõlgendamise juures peame silmas pidama, et erakonna $\mathrm{x}$ häälte osakaalu mõju põhiseaduse muutmise toetusele ei ole välja arvutatud mitte universaalselt 50-protsendilise poolthäälte osakaalu, vaid iga rahvahääletuse konkreetse ettepaneku toetuse keskmise suhtes. ${ }^{57}$

1932. AASTA PÕHISEADUSE RAHVAHÄÄLETUS. 1932. aasta augusti rahvahääletusel sai põhiseaduse muutmise ettepanek napi kaotuse osaliseks - seda toetas 49,2 protsenti hääletanutest. Vaadates toetuse ruumilist jaotust, mida on kujutatud joonisel 1, siis on näha maa ja linna selget erisust: kui valdade keskmine toetushäälte osakaal oli 57,2, siis linnade-alevite oma 31,9 protsenti. Lisaks linnadele-alevitele oli toetus madal idapoolsetel piirialadel, aga ka Viljandi-, Valga-, Harju- ja Tartumaa keskosas. Samas oli toetus kõrge Lääne-, Järva- ja Virumaal ning eriti Kagu-Eestis.

Ettepaneku tagasilükkamine oli ootamatu, kuna mõni kuu varem said ettepanekut toetanud erakonnad ülekaaluka enamuse riigikogus. Kuid antud rahvahääletuse puhul kehtestati hääletamiskohustus, mis tõstis osalusprotsenti V riigikogu valimiste 67-lt 90,5 protsendile ehk hääletusurni juures võis käia märksa teistsugune elektoraat. ${ }^{58}$ Rein Marandi on leidnud,

54 Valdade kohta andmed võetud: Valdade rahvastik (Tallinn: Eesti Statistika Keskbüroo, 1934), 58-103; linnade kohta: H. Reiman, "Rahvastiku tööharud ja ühiskondlik kihitus Eestis", Eesti Statistika, 6 (1935), 286, 290.

55 Elanikkond on jaotatud neljaks töösuhte järgi. Lisaks aktiivsetele on kategooriad palgata tööd tegevad pereliikmed (peamiselt taludes), kodumajapidamistes tegevad pereliikmed (peamiselt koduperenaised linnas) ja ülalpeetavad (lapsed, raugad ja teised). 56 Valdade kohta andmed võetud: Valdade rahvastik, 25-35; linnade ja alevite kohta: Rahvastiku koostis ja korteriolud (Tallinn: Eesti Statistika Keskbüroo, 1934), 4.

57 Silmas peetud keskmist omavalitsustes tulemuste lõikes.

58 Lisaks suurendas trahvihirm ka hääleõiguslike arvu ennast, kuna valijate nimekirju täideti usinamalt kui mittekohustuslikel valimistel ja rahvahääletustel. Hilisematel 


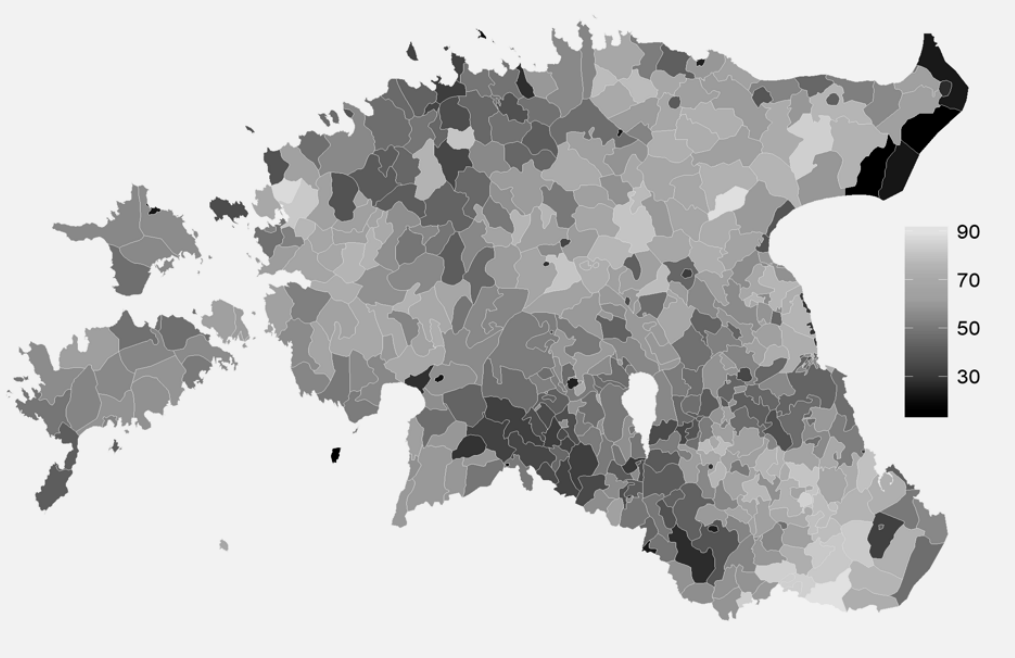

Joonis 1. 1932. aasta rahvahääletuse ettepaneku toetusprotsent.

et vabatahtlikkuse ja normaalse aktiivsuse korral oleks juba u 35 protsenti hääleõiguslikke kodanikke võinud põhiseadust muuta, kohustuslikkuse korral tõusis see kvoorum aga 45 protsendile. ${ }^{59}$ Niisiis tekib küsimus, kas riigikogu tegi rahvahääletust kohustuslikuks muutes vea. Võiks näida loogiline, et trahviähvardus tõi valimiskastide juurde ka keskmisest ükskõiksemad kodanikud, kes muidu valima tulnud ei oleks, ning keda hääletussund pigem trotslikuks, st pigem vastuhääletajaks suunas. Lisaks toimus referendum kõige kiiremate põllutööde ajal. Seda, et sundus võis tekitada protesti, näitab asjaolu, et hääletussedeli rikkumist esines võrreldes vabatahtlike hääletustega rohkem. ${ }^{60}$

Vaadates osalusprotsendi hajuvust, siis oli variatsioonikordaja ${ }^{61}$ esimesel põhiseaduse muutmise rahvahääletusel 3 , samas kui V riigikogu valimistel 13 ning kahel järgneval põhiseaduse muutmise rahvahääletusel vastavalt 12 ja 9 protsenti, mis viitab selgelt, et seadusesund tõstis rohkem aktiivsust omavalitsustes, kus tavapäraselt oli madalam aktiivsus. Testimaks hüpoteesi, et hääletamissundus tõstis vastuhääletajate osakaalu, lisasime

rahvahääletustel kadus see osa valijaid taas ära, vt Tooms, Rahvahääletused põhiseaduse, 605 .

59 Marandi, Must-valge lipu all, 49.

60 Täpsemalt 1,9\% võrreldes o,6\% ja o,4\% järgnenud kahel rahvahääletusel, vt Tooms, Rahvahääletused põhiseaduse, 606.

${ }_{61}$ Standardhälve jagatud aritmeetilise keskmisega. 


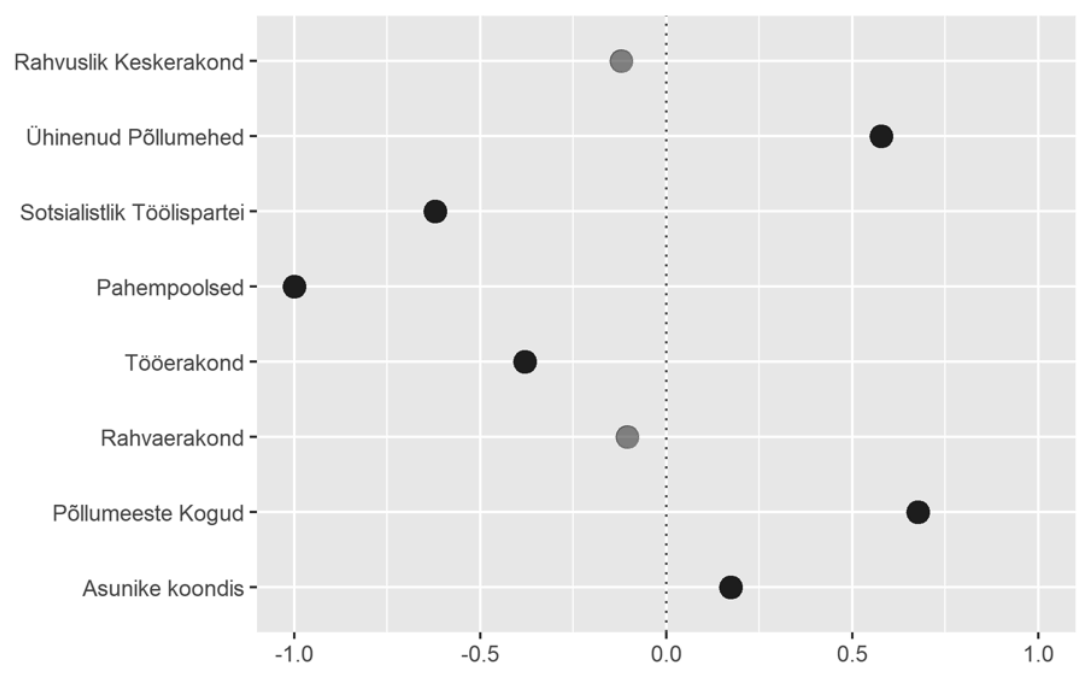

Joonis 2. Erakondade elektoraadi mõju 1932. aasta juuni rahvahääletuse tulemustele. Lineaarse regressiooni tulemused..$^{62}$

regressioonimudelisse üheks seletavaks tunnuseks ka hääletusaktiivsuse muutuse võrreldes $\mathrm{V}$ riigikogu valimistega. See tunnus annab edasi lisandunud valijaskonna mõju põhiseaduse muutmise toetusele. Täpsemalt, kas kehtib seaduspärasus, et mida rohkem tõusis aktiivsus võrreldes tavapärasega, seda rohkem oli vastuhääletajaid. Mudelite tulemused näitavad, et "uue valijaskonna" mõju rahvahääletuse tulemusele on neutraalne ehk nemad ei saanud kaalukeeleks.

Edasi keskendume poliitiliste jõudude mõjule referendumi resultaadile. Regressioonimudelite tulemused (8 mudelit) on esitatud joonisel 2. Sel ning edasistel joonistel tähistavad poolenisti läbipaistvad punktid, nagu joonisel 2 kahe erakonna puhul, statistilise olulisuse puudumist ehk vastava faktori mõju põhiseaduse muutmise toetusele võrdub (sisuliselt) o-ga. Põhiseaduse muutmise toetust tõstvate faktorite punktid (võrreldes keskmisega) asuvad o-st paremal ning kahandavate punktid o-st vasakul.

62 Siin ja järgnevate referendumite osas on iga poliitilise jõu mõju on hinnatud eraldi mudeliga, kus kontrolltunnusteks on mitte-eestlaste osakaal, algharidusest kõrgema haridusega meeste osakaal, agraarsektorist elatust saavate osakaal, iseseisvat sissetulekut teenivate osakaal, 20-24-aastaste osakaal üle 20-aastastest elanikest ning valimisaktiivsuse muutus võrreldes vahetult eelneva hääletusega. Usaldusintervalliks on võetud $90 \%$ ja statistilise olulisuse puudumist tähistab hall punkt. 
Kommunistid olid kindlalt põhiseaduse muutmise vastu ning rahvahääletuse tulemustest selgub, et vastu oli ka nende toetajaskond. Pahempoolsete nimekirja osakaalu üheprotsendiline tõus 1932. aasta mais toimunud $\mathrm{V}$ riigikogu valimistel langetas juunis toimunud rahvahääletusel toetust ettepanekule 1,05 protsendi võrra. Ka ESTP valijad järgisid erakonna juhtkonna seisukohti, samas mitte nii selgelt eristudes.

Ühinenud põllumeeste erakond toetas endiste Põllumeeste Kogude juhtide mõjutusel põhiseaduse muutmist ning saavutas samuti oma valijaskonna toetuse. Seejuures andis just Põllumeeste Kogude valijaskond märksa tugevama toetuse. Nii tõstis Põllumeeste Kogude häälte osakaalu üheprotsendiline kasv IV riigikogu valimistel rahvahääletuse toetust o,68 protsendi võrra, samas kui Asunike Koondise vastav näitaja on üle kolme korra madalam.

Rahvusliku Keskerakonna toetamisel V riigikogu valimistel aga puudus mõju esimese põhiseaduse muutmise eelnõu toetamisele. Vaadates ühenderakonna kaht poolt - Tööerakonda ja Rahvaerakonda - näeme vastandlikke tulemusi. Tööerakonna häälte osakaalu tõus IV riigikogu valimistel viis toetust rahvahääletusel hoopis alla (-0,38\%), samas kui Rahvaerakonnal sisuline mõju puudus.

Järeldagem, et Rahvusliku Keskerakonna valijad ei asunud oma esindajate poolt välja töötatud ettepanekute taha - eriti paistavad siinkohal silma endised Tööerakonna toetajad. Küsimusele, miks mõni kuu varem keskerakonda valinud inimesed oma esindajate poolt välja töötatud eelnõud nii vähe toetasid, võib järgmise ja ülejärgmise rahvahääletuse tulemustele toetudes vastata, et see oli IV riigikogu valimistel Rahvaerakonda toetanud kodanikele pigem liiga vähe radikaalne ja Tööerakonna toetajatele liiga radikaalne. Rahvusliku Keskerakonna juhtkond ei olnud suutnud oma valijaid selles küsimuses veenda ja ühenderakonna kaht suuremat poolt konsolideerida.

1933. AASTA JUUNI RAHVAHÄÄLETUS. Järgmine rahvahääletus toimus 10 kuud hiljem - 1933. aasta juunis. Seekord lükati ettepanek tagasi ülekaalukalt - poolt oli vaid 32,7 protsenti hääletamas käinutest. Joonisel 3 on kujutatud poolthäälte osakaalu omavalitsuste kaupa. Ka nüüd oli maal põhiseaduse muutmise toetamine populaarsem kui linnas - keskmised protsendid vastavalt 36,7 ja 25,5. Erinevus maa ja linna vahel oli väiksem, kuna maal oli toetuse langus tunduvalt suurem. Võrreldes varasema referendumiga kasvas põhiseaduse muutmise toetuse protsent 59-s omavalitsuses 407-st, eelkõige Harju-, Viru-, Pärnu- ja Petserimaal. Samas langes poolthäälte 


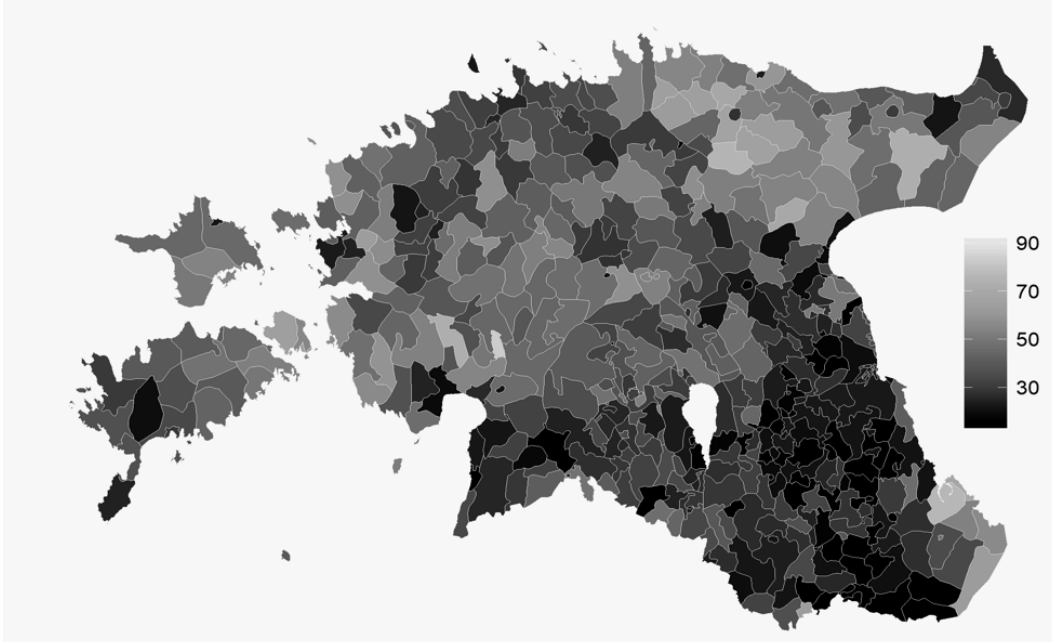

Joonis 3. 1933. aasta juuni rahvahääletuse ettepaneku toetusprotsent.

protsent neljakümne punkti võrra 62-s omavalitsuses, esmajoones Võruja Tartumaal. Poolthäälte osakaalu korrelatsioon omavalitsuseti on madal - kõigest 23 protsenti, st et põhiseaduse toetamise protsendi sarnasus kahe rahvahääletuse võrdluses omavalitsuseti on madal.

Hääletamine ei olnud kohustuslik ning ka osalusprotsent langes 90 protsendi juurest tagasi 66,5-le. Absoluutarvudes "ei"-häälte arv tegelikult langes veidi $(3,6 \%)$, kuid "jah"-häälte üldarv langes samal ajal üle poole. Seega võib pakkuda hüpoteesi, et seekordne rahvahääletus oli suuresti pettunud kodanike protestiaktsioon, st eelmisel rahvahääletusel poolthääle andnud jäid koju.

Seetõttu vaadelgem esmalt, mis määras hääletamisaktiivsuse ning selle muutuse võrreldes 1932. aasta augustikuuga. Vastavatest mudelitest selgub, et poliitiliste erakondade toetusel oli valimisaktiivsusele (ja selle muutusele) marginaalne mõju ehk sunduse kadudes tulid teistkordselt põhiseaduse muutmise osas hääletama tavapäraselt valimas käijad, mitte ei olnud aktiivsus mõjutatud mõne erakonna eriti mõjusast poolt- või vastupropagandast.

Küll aga on hääletamisaktiivsusel ning selle muutusel, erinevalt eelmisest rahvahääletusest, mõju rahvahääletuse ettepaneku tagasilükkamisele. Nii tähendab kõrgem osalus ja osaluse väiksem langus võrreldes eelneva referendumiga 0,4-protsendilist kahanemist põhiseaduse ettepaneku toetamisele. See viitaks, et koju jäid paljud varasemalt põhiseaduse muutmist toetanud inimesed. Siiski peame meeles pidama esimese põhiseaduse 


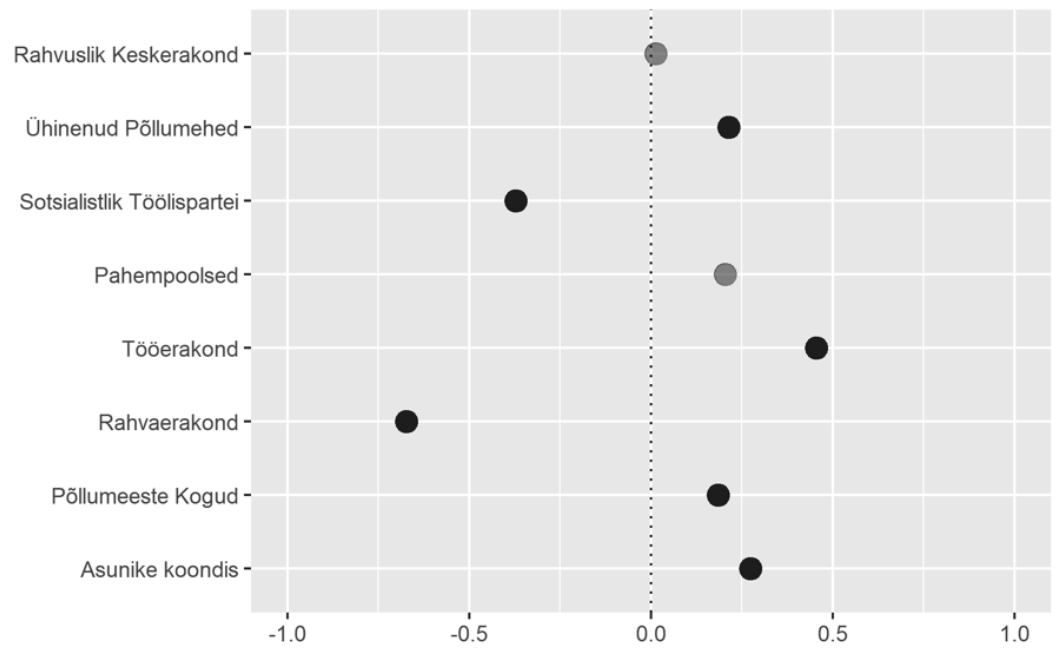

Joonis 4. Erakondade elektoraadi mõju 1933. aasta juuni rahvahääletuse tulemustele. Lineaarse regressiooni tulemused.

rahvahääletuse sunduslikku, kuid ettepaneku toetamist mittemõjutanud iseloomu. Nii järeldame, et käsitletaval rahvahääletusel toimus ka suure osa tavaliselt valimas käijate meelsuse muutumine.

Sarnaselt eelmise rahvahääletusega on ettepaneku toetus madalam omavalitsustes, kus oli rohkem sotsialistide pooldajaid, kuid seekord eristuvad kommunistide pooldajad, andes positiivse märgiga, kuigi statistilise olulisuseta kordaja. Seda tulemust on raske selgitada. Marksistide vastasseisu mõju alanemist tervikuna võib ehk põhjendada see, et oma kihutustöö teravikku ei suunatud seekord mitte niivõrd rahvale esitatud ettepaneku kuivõrd vabadussõjalaste vastu. Samuti võib selgituseks tuua, et mitte-marksistlike jõudude toetajad andsid võrreldes varasemaga rohkem "ei"-hääli, st marksistide valijate vastuseis eristus vähem, kuna poolthäälte osakaalu keskmine ise oli võrreldes varasemaga langenud.

Agraarerakondade mõjusuund ei olnud võrreldes varasema referendumiga muutunud, kuid tugevus oli vähenenud (välja arvatud Asunike Koondise valijatel). Osaliselt tuleneb see asjaolust, et vastavate erakondade valijaid jäid võrreldes eelmise referendumiga rohkem koju. Kuid märkimisväärne hulk muutis siiski oma hääle eitavaks. Põhjus võib olla uue projekti ettenähtud muutuste pehmus, kui ka süvenenud majandusraskustest tingitud üldise rahulolematus. Kaudse vastuse annavad mudelid, kus sõltuvaks muutujaks on poolthäälte osakaalu muutus võrreldes eelmise 
rahvahääletusega. Ühinenud agraarerakonna ja Põllumeeste Kogude toetajatel on neis selge negatiivne mõju, samas kui Asunike Koondise toetajate mõju toetusprotsendi muutusele puudub. See viitab, et Põllumeeste Kogude valijaskond ei olnud rahul nende ette pandud projekti ulatusega, kuna just asunikud olid majanduskriisist rohkem mõjutatud kui Põllumeeste Kogude "vanapõllumehed".

Rahvusliku Keskerakonna pooldajate mõju oli aga sarnaselt eelmise rahvahääletusega olematu. See näib olevat seotud ühise erakonna kahe põhilise tiiva valijate erineva käitumisega. Tööerakonna poolehoiu üheprotsendiline kasv tähendas juunis 1933 põhiseaduse toetamise mõju kasvu 0,46 protsenti (augustis 1932 oli vastav efekt -0,38\%). Rahvaerakonna vastav näitaja oli aga -0,67 protsenti (augustis 1932 sisuline mõju puudus). Seega järeldame, et Rahvaerakonna valijad olid eelnõuga väga rahulolematud, samas kui just endine Tööerakonna elektoraat järgis seekord ühinenud keskerakonna juhtide juhiseid.

1933. AASTA OKTOOBRI RAHVAhäÄLETUS. Neli kuud hiljem, 1933. aasta oktoobris toimunud kolmanda põhiseaduse rahvahääletuse tulemused olid sootuks teistsugused. Vabadussõjalaste poolt välja töötatud ja rahvaalgatuse korras esitatud eelnõud toetas 72,7 protsenti hääletanutest, mistõttu on joonis 5 , mis kujutab toetust omavalitsuste kaupa, võrreldes varasematega tunduvalt heledam. Seekord valisid linnad-alevid ja maapiirkonnad sarnaselt, poolthäälte protsent oli vastavalt 70,9 ja $73,7 \cdot{ }^{63}$ Kõrge poolehoiuga paistavad silma varasematelgi referendumitel põhiseaduse eelnõusid keskmisest enam toetanud Viru-, Järva-, Lääne- ja Pärnumaa alad. Kõige kõrgem oli toetus aga hoopis augustis 1932 põhiseaduse muutmist enim toetanud, kuid juunis 1933 enim vastu olnud Tartu- ja Võrumaal. Nii on tulemuste korrelatsioon eelmise rahvahääletusega -19 protsenti, 1932. aasta rahvahääletusega 55 protsenti, mis viitab, et tulemused olid omavalitsuste kaupa tunduvalt sarnasemad esimese põhiseaduse muutmise osas peetud referendumiga.

Hääletamisaktiivsus tõusis üle kümne protsendipuntki 77,9-ni. Agraarerakondade valijad käisid valimisurni juures neli kuud varasema ajaga võrreldes veidi rohkem, samas kui sotsialistide ning Rahvaerakonna valijad veidi vähem. Kuid see mõju on väike, jäädes ühe protsendikümnendiku juurde ehk suurt tõusu aktiivsuses ei saa seletada erakondade kihutustööga. Kõrgemal aktiivsusel oli mõju rahvahääletuse ettepaneku toetamisele.

63 Linnade ja alevite puhul on antud rahvastiku alusel kaalutud keskmine. Linnades oli toetus 71,7 ja alevites $60,1 \%$. 


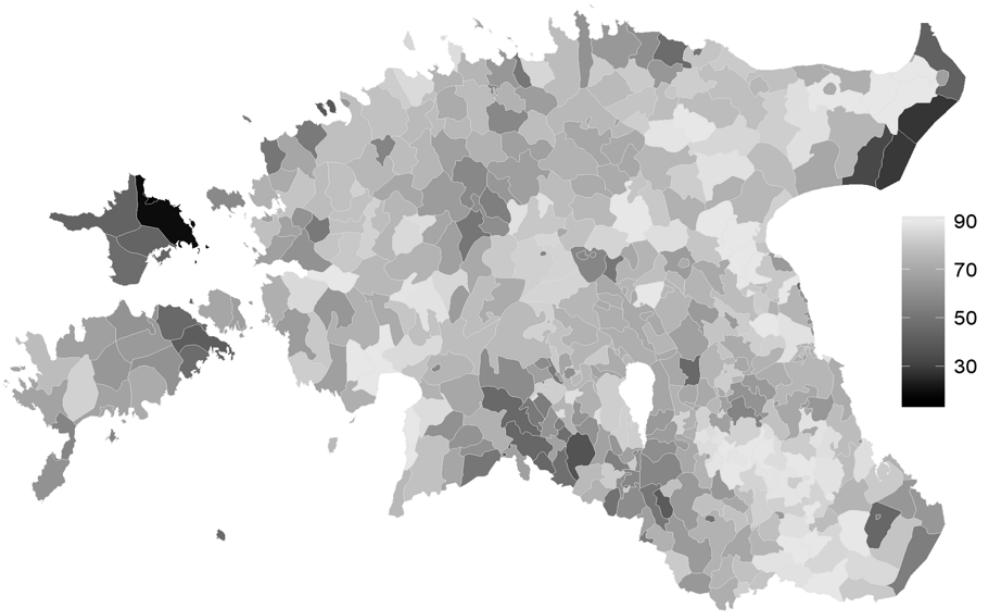

Joonis 5. 1933. aasta oktoobri rahvahääletuse ettepaneku toetusprotsent omavalitsusteti.

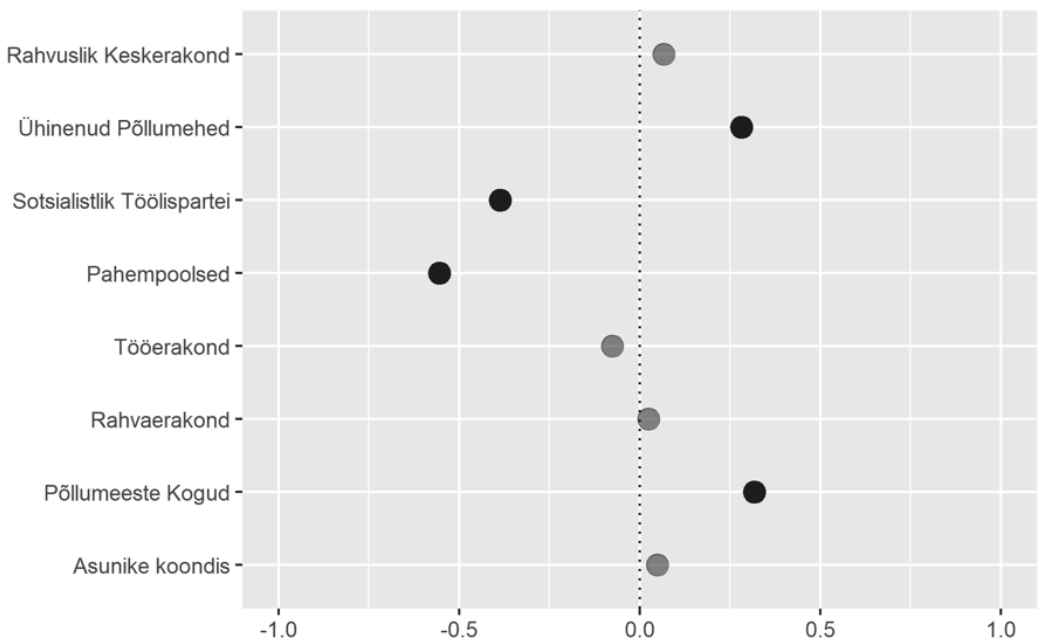

Joonis 6. Erakondade elektoraadi mõju 1933. aasta oktoobri rahvahääletuse tulemusele. Lineaarse regressiooni tulemused. 
Üheprotsendiline tõus hääletusaktiivsuses suurendas poolthäälte osakaalu ning selle muutust võrreldes eelneva referendumiga 0,5 protsendi võrra.

Võrreldes varasemate rahvahääletustega on joonisel 6 olevad punktid nullile lähemal ning enamad on statistilise olulisuseta, mis viitab erakondade mõju langusele põhiseaduse muutmise küsimuses. Kõige kindlamalt - ehkki mitte nii kindlalt kui esimesel põhiseaduse rahvahääletusel - olid vastu kommunistide pooldajad. Sama võib öelda ESTP elektoraadi kohta, ent nemad olid ka esimesel põhiseaduse rahvahääletusel vähem vastu olnud, mis tõestab kaasaegsete ning hilisemate uurijate väiteid, et ka osa töölistest asusid vabadussõjalaste ettepaneku taha.

$\mathrm{Ka}$ agraarerakondade toetusel on varasemate referendumitega sarnane mõju. Nimelt siis oli kolmanda põhiseaduse rahvahääletuse ettepaneku pooldamine kõrgem omavalitsustes, kus valiti enam Põllumeeste Kogusid ning ühinenud põllumeeste erakonda. Asunike Koondise kõrgem toetus keskmisest ei eristunud. Tuletame meelde, et asunike riigikogu fraktsioon ei võtnud vabadussõjalaste ettepaneku osas ühist seisukohta.

Keskerakondade valijaskonna tõus rahvahääletuse toetuse tasemele mõju ei avaldanud, kuigi ühinenud keskerakonna juhtkond sellele tuliselt vastu oli. Kuid vaadates toetuse muutuse mudeleid ehk poolthäälte osakaalu tõusu võrreldes eelmise rahvahääletusega, pakub huvitava pildi taas Tööerakonna ja Rahvaerakonna mõju võrdlus. Eelmisel rahvahääletusel keskmisest rohkem toonast põhiseaduse muutmise ettepanekut toetanud Tööerakonna toetajad ei läinud nüüd põhiseaduse eelnõu toetamisega nii suurel määral kaasa kui teiste erakondade valijad, kordaja -0,6 protsenti. Rahvaerakonna valijaskond aga, kes eelmisel rahvahääletusel Tõnissoni valitsuse ja Postimehe kiidetud ettepaneku otsustavalt tagasi lükkas, asus nüüd jõuliselt vabadussõjalaste eelnõud toetama, kordaja $0,78 \%$. Nii saame näha taas Jaan Tõnissoni ja tema Rahvaerakonna erilist langust endiste toetajate silmis.

\section{Arutlus ja kokkuvõte}

Niisiis, kuidas hääletas rahvahääletustel erinevate erakondade elektoraat ning kas tegemist oli poliitilise maalibisemisega, nagu sõnastas Artur Mägi, st üleminekuga vabadussõjalaste poolele?

Tulemuste kokkuvõttes on võimalik tuvastada erakondade mõju sammsammulist vähenemist, kuid selle ulatus oli erakonniti väga erinev. Esiteks hääletas agraarerakondade elektoraat üldjuhul oma erakondade juhtide 
seisukohti järgides - see tähendab, et Põllumeeste Kogude ja nende poolt domineeritud Ühinenud Põllumeeste erakonna suurem toetusprotsent riigikogu valimistel tähendas keskmisest suuremat toetust põhiseaduse muutmise ettepanekule, kusjuures 1933. aasta juuni rahvahääletusel on näha osa Põllumeeste Kogude valijate rahulolematus ettepaneku väheradikaalsete sätetega. Asunike Koondise toetajaskond, nagu ka juhtkond, oli põhiseaduse muutmise osas neutraalsem. Seega ja arvestades ka 1934. aasta kohalikke valimisi, kus vabadussõjalased said valdades vaid 8,9 protsenti häältest, pole mingit alust arvata, et agraarerakonnad oleksid oma elektoraadist kuigivõrd suure osa kaotanud. ${ }^{64}$

Selle artikli uuenduslikuma tulemusena on selgunud Rahvusliku Keskerakonna põhielektoraadi väga lahknev käitumine. Need valijad, kes olid IV riigikogu valimistel toetanud Rahvusliku Keskerakonna vasakpoolset osapoolt Tööerakonda, hääletasid esimesel põhiseaduse rahvahääletusel Rahvusliku Keskerakonna juhtkonna juhtnööride vastaselt, teisel kindlamalt juhtkonna seisukohtade kohaselt ning kolmandal taas suures osas erakonna ametliku seisukoha vastaselt. Seevastu Rahvusliku Keskerakonna parempoolse tiiva - Rahvaerakonna - valijad hääletasid esimesel põhiseaduse rahvahääletusel sarnaselt üleriigilise keskmisega, mis viitab osa Rahvaerakonna toetajate irdumisele erakonna juhtide seisukohast. Teisel ja ka kolmandal põhiseaduse rahvahääletusel hääletati juba kindlalt oma erakonna juhtnööride vastaselt.

Seega võime teha järelduse, et esimese põhiseaduse eelnõu napp läbikukkumine oli tingitud asjaolust, et Rahvusliku Keskerakonna juhtkond ei olnud suutnud oma elektoraadile põhiseaduse muutmise kava korralikult põhjendada. Suur osa Tööerakonna valijaid ei pidanud esimesel põhiseaduse muutmise rahvahääletusel poolthääletamist võimalikuks ilmselt seetõttu, et pidasid muudatust sarnaselt Eesti sotsialistidega liiga radikaalseks, osa Rahvaerakonna valijaist aga seetõttu, et pidasid muudatust sarnaselt vabadussõjalastega liiga vähe radikaalseks. Nii näib, arvestades ka kolmanda põhiseaduse rahvahääletuse tulemusi - et just Rahvaerakonna

64 Valimistulemuse kohta on erineva metoodikaga teinud arvutusi Olaf Kuuli ("Parlamendi- ja kohalike omavalitsuste valimised kodanlikus Eestis 1930-ndatel aastatel ja Eestimaa Kommunistliku Partei taktika", Tartu Riikliku Ülikooli Toimetised. Töid NLKP ajaloo alalt, 351 (1975), 109-116), Eerik-Juhan Truuväli (Valimisõigus ja valimised Eestis 1917-1980, I: valimisõigus ja kohalike esindusorganite valimised 1917-1939 (Tallinn: Eesti Raamat, 1986), 190-194, 239) ja Ants Ruusmann (Eesti Vabariik 1920-1940 (Tallinn: TPÜ kirjastus, 1997), 102-103). Siinkirjutaja hinnang põhineb linnade osas Päevalehe andmetele ("Linna- ja alevivalimiste üldpilt selgus", Päevaleht, 17.01.1934), valdade ja alevite osas aga Siseministeeriumi omavalitsuste talituse kokkuvõttetabelitele (RA, ERA.40.1.506, 1. 387-388; 390-391). 
kui rahvusliku erakonna valijad võisid kõige rohkem olla sattunud vabadussõjalaste sõiduvette ka muudes küsimustes.

Sotsialistide ja kommunistide valijaskond aga hääletas pigem oma erakonna juhtnööride järgi ehk muutmise vajadust eitavalt. Erandiks on kommunistide valijaskonna käitumine teisel põhiseaduse rahvahääletusel, mil kommunistide toetusel sisuline mõju hääletustulemusele puudus. Viimasel referendumil on siiski näha, et osa sotsialistide toetajatest hääletas oma esindajate seisukohtade vastu. Sotsialistide juhtkonna teatavale võõrandumisele oma valijatest viitavad ka 1934. aasta alguse kohalike valimiste tulemused. Tõestust ei leia aga väide, et kommunistide pooldajaskond oleks kuigivõrd arvestataval määral asunud vabadussõjalaste põhiseaduse eelnõud toetama.

Kokkuvõttes - kui jätta välja Rahvaerakonna pooldajate valimiskäitumine referendumitel - ei sarnane referendumite tulemused siiski poliitilise maalibisemisega ehk valijaskonna täieliku võórandumisega nende erakondade seisukohtadest, kelle poolt oldi hääletanud riigikogu valimistel. 1933. aasta oktoobri referendumil võis elektoraat olla ka lihtsalt põhiseaduse referendumitest tüdinenud ja ihata lõpuks lahenduseni jõudmist. "Jah"-häälte andmist soodustas ilmselgelt ka riigikogu otsus teha rahvahääletusseaduse muutmisega eelnõu vastuvõtmine raskemaks.

Missugune oli aga vabadussõjalaste tegelik toetusbaas 1933. aasta lõpul ja 1934. aasta esimestel kuudel? Kas on alust arvata, et 1934. aasta riigipea valimistel võitnuks vabadussõjalaste kandidaat ja riigikogu valimistel võinuksid vabadussõjalased saada enamuse?

Riigivanema valimiste puhul on põhiseaduste referendumite alusel raske mingeidki prognoose teha, kuna toetus ühele või teisele kandidaadile sõltus tugevasti ka nende isiklikust karismast ja kampaaniast. Igatahes ei tähendanud vabadussõjalaste kandidaadile Andres Larkale tema kandidatuuri ülesseadmisel antud suur toetushäälte hulk võrreldes teiste kandidaatidega tema ülihäid šansse valimistel. ${ }^{65}$ Maaelanikkonna hulgas oli selgelt populaarseim siiski Johan Laidoner. ${ }^{66}$

65 20. märtsil 1934 oli toetusallkirjade lõppseis erinevate andmete järgi mõnevõrra erinev, aga Andres Larkal üle 6o ooo, Johan Laidoneril üle 38 ooo, Konstantin Pätsil üle 18000 ja August Reil ligi 5000 allkirja (Marandi, Must-valge lipu all, 393; Eesti ajalugu VI, 91). Ent arvestada tuleb, et pärast 12. märtsi pidi Larkale antavate allkirjade hulk vähenema kodanike kartuse tõttu end riigivastases tegevuses süüdistatava poliitilise jõuga siduda. 66 Olemasolevate toetusallkirjalehtede andmed on tabuleerinud ja kokku arvestanud Tartu Ülikooli ajalooüliõpilane Helen Rebane (arvutusalus: Kodanike allkirjad Johan Laidoneri riigivanema kandidaadiks esitamise kohta: RA, ERA 80.5.2211; ERA.80.5.2137; ERA.80.5.2137a; ERA.80.5.2137b; ERA.80.5.2137c; Kodanike allkirjad Andres Larka riigivanema kandidaadiks esitamise kohta: RA, ERA.80.5.2139; ERA.80.5.2139a; 
Riigikogu valimiste osas on võimalik pakkuda mõnevõrra kindlamaid prognoose. 1934. aastal vastu võetud uue valimisseaduse kohaselt said valijad hääletada ringkondades nii erinevate kandidaatide poolt, reastades kolm kõige soovitumat kandidaati, kui ka nimekirjade poolt, missugusel juhul reastati kandidaadid häälte kokkulugemisel selle järgi, kuidas nad nimekirjade esitamisel olid järjestatud. Erakondade saadud kohtade arv riigikogus määrati üleriiklike kokkuvõtete järgi, ning neile kohtadele pidid asuma ringkondades võrdlevalt kõige rohkem hääli saanud kandidaadid. ${ }^{67}$

Seega määras kohtade arvu erakondade üleriigiline populaarsus. Nagu mainitud, oli vabadussõjalaste populaarsus maa keskklasside hulgas madal, mida tõestavad nii kohalike valimiste tulemused kui ka riigivanema kandidaatide toetusallkirjad. Ka põhiseaduse referendumite tulemused tõestavad, et agraarerakonnad ei kaotanud kuigi olulisel määral oma elektoraati. Kui arvestada, et V riigikogu valimistel 1932. aastal oli ühendatud põllumeeste erakond saavutanud 42 protsenti kohtadest, siis pole alust arvata, et 1934. aasta aprilliks oleks nüüd lagunenud erakonna kahe osapoole häältesaak kahanenud rohkem kui viiendiku võrra. Seega võiks arvestada, et ärajäänud aprillivalimistel oleksid agraarerakonnad saavutanud minimaalselt 36 protsenti kohtadest.

Rahvuslik Keskerakond oli V riigikogu valimistel saavutanud 23 protsenti kohtadest. Põhiseaduse referendumi tulemustest võib järeldada nende üsna tugevat häältekadu ühenderakonna ühe suurema osapoole Rahvaerakonna arvel. Teise, vasakpoolse osapoole - Tööerakonna - valijate häältekadu aga ei saanud vabadussõjalastele nii suur olla, mida võib väita nii asjaolu tõttu, et Tööerakonna valijad olid vabadussõjalastest ideoloogiliselt kaugemad, kui ka põhiseaduse referendumite tulemuste järgi. Kuid kui ka oletada, et häältekadu moodustas Rahvusliku Keskerakonna puhul 60 protsenti, ka siis oleks see erakond pidanud aprillivalimistel saavutama minimaalselt 9 protsenti kohtadest.

Eesti Sotsialistlik Tööliste Partei oli saavutanud V riigikogu valimistel 22 protsenti kohtadest. Kindlasti mõjutas erakonna lõhenemine 1934. aasta veebruaris ESTP populaarsust negatiivselt, kuid on raske uskuda, et neist erakonna senistest toetajatest, kes pettusid ESTP-s, oleks enamik 1934. aasta aprillis hääletanud vabadussõjalaste ehk marksistide ideoloogilise vastase poolt. Pigem oleks pettunud toetajaskond jätnud hääletamata

ERA.80.5.2139b; ERA.80.5.2139c; ERA.80.5.2139d; ERA.80.5.2139e; Kodanike allkirjad Konstantin Pätsi riigivanema kandidaadiks esitamise kohta: RA, ERA.80.5.2136; ERA.80.5.2136a; Kodanike allkirjad August Rei riigivanema kandidaadiks esitamise kohta: RA, ERA.80.5.2138).

67 Riigi Teataja, 5 (1934), 105-128. 
või hääletanud kommunistide või mittemarksistlike vanade erakondade poolt. Isegi kui oletada, et sotsialistid kaotasid poole oma elektoraadist, oleks säilinud osa pidanud neile 1934. aasta aprillis tooma minimaalselt 11 protsenti kohtadest.

Kommunistide pooldajad olid viimasel rahvahääletusel olnud kõige kindlamalt vabadussõjalaste põhiseaduse vastu. Raske on uskuda, et ka vähemusrahvuste pooldajad, keda võib pidada kõige lojaalsemaks, oleks oma valikuid muutnud suures osas vabadussõjalaste kasuks. Nagu mainitud, siis oli meie mudelites üheks kontrolltunnuseks ka mitte-eestlaste osakaal, mis näitas selgelt, et vähemusrahvused hoidusid vabadussõjalaste ettepanekud toetamast. Vähemusrahvuste erakonnad ja kommunistid olid V riigikogu valimistel saanud kokku 13 protsenti häältest. Kui oletada, et nende häältesaak kahanenuks aprillivalimistel kolmandiku võrra, oleksid nad ikkagi saanud minimaalselt 9 protsenti kohtadest. Arvestuse kokkuvõttes näib, et vabadussõjalaste maksimaalseks tulemuseks võinuks olla 35 protsenti häältest.

Seega võiks prognoosida, et vabadussõjalastel polnud võimalik parlamendivalimistel saavutada enamust, vaid pigem ligikaudu kolmandik kohtadest. Seetõttu - isegi eeldades, et vabadussõjalased olid demokraatiavastased - toonitagem, et selleks eelduseks puudub selge alus - pole põhjust arvata, et ühiskonna enamus eelistas autoritaarset valitsemisvormi. Kolmandal põhiseaduse rahvahääletusel andsid oma poolthääle eelkõige linnade ja maa keskkihid, keda peetakse üldiselt demokraatia toeks. Seejuures näib, et erakondade toetajatest asus kõige rohkem vabadussõjalasi toetama Rahvaerakonna valijaskond. Nii on väga kaheldavad ka väited, et 12. märtsi riigipöörde näol oli tegemist autoritaarsust ennetava võimuvõtuga ning Eesti ühiskond järgis Lääne autoritaarsuse eeskuju.

Aвstract: Political attitudes in Estonian society in the pivotal years of 1932-1934

This article deals with the Constitutional crisis of the Estonian Republic and analyses the results of the three referendums (August of 1932, June of 1933, and October of 1933) that took place on the three different amendment proposals to the 1920 constitution. Thus, unlike previous research that has 
mostly looked at the topic of the political crisis from the viewpoint of the political elite and the leaders of the the League of Veterans movement, we map the moods and opinions of the electorate during this volatile time. To be more precise, we try to find out the parties whose supporters voted for amending the constitution and the parties whose supporters did not. We link this with the official stances of the said parties and see whether or not their supporters aligned their votes with their representatives. Additionally, on the basis of the last referendum, where people voted on the proposal of the League of Veterans, we speculate on what percentage of votes the movement could have obtained in the parliamentary elections scheduled for 1934 .

We use linear regression, which is one of the most widely used quantitative models, to achieve this. The level of analysis is the local government (town, village, rural municipality), since we do not have individual level data from public opinion polls from this era. Linear regression assumes a relationship between a variable of interest (is our case: support for party $\mathrm{x}$ in an election) and the outcome variable (in our case: support for amending the constitution). Additionally, we add control variables to the model, to distinguish the direct effect of support for a political party on support for amending the constitution.

We use not only the results from the 1932 parliamentary elections, but also those from 1929. This is due to the fact that the party system changed before the 1932 elections. The two agrarian parties formed a unified party (the Union of Settlers and Smallholders). Konstantin Päts' Farmers' Assemblies (Pôllumeeste Kogud) that represented the wealthier established farmers was very much in favour of constitutional amendments. The Settlers' Party (Asunikud), which represented small-holders, was neutral to this. A unified party was also established in the political centre (the National Centre Party). However, the parties had different stances here as well. Jaan Tõnissons' centre-right People's Party (Rahvaerakond) was very supportive of constitutional change, while the centre-left Labour Party (Tööerakond) was not. The leadership of both of these consolidated parties went to fractions that supported the revision of the constitution.

In August of 1932, a proposal put forward by the Estonian Parliament (Riigikogu) was surprisingly rejected - only $49.2 \%$ of the electorate supported it. The analysis shows that greater support for the Union of Settlers and Smallholders in 1932 and for the Farmers' Assemblies in 1929 predicts greater support for the amendment proposal. For the Settlers' Party, the result is weaker, but still positive. The relationship is inverse 
for the Socialists and Communists. All of this is to be expected since the unified agrarian party was for the motion and the Marxist parties were against it. In the political centre, however, we can see unexpected results. The National Centre Party does not have a statistically significant effect on the results of the referendum. This is also true for the People's Party. For the Labour Party, we see a negative relationship, which indicates that their supporters rejected the stance of the unified party and voted against the constitutional amendment. For many supporters of the People's Party, the amendments were probably not radical enough.

In June of 1933, the Riigikogu's second proposal was overwhelmingly rejected - only $32.7 \%$ of the electorate supported it. It is important to note that this motion was weaker in its rearrangements than the previous one. For the agrarian parties, we can still see a positive relationship - a higher percentage of support for them also meant greater support for the amendment. This, however, is much weaker that previously, reflecting the view of their electorate that the proposed changes were not radical enough. The support of the Social Democrats still has a negative effect on the results, while support for the Communists has a statistically insignificant effect. Again, at the political centre we see the most noteworthy results. Greater support for the People's Party predicted less support for the second amendment proposal, while greater support for the Labour Party predicted greater support for the amendment. This means that by this referendum, the People's Party had very little influence on their electorate, who rejected the small-scale reforms convincingly. This time it was the supporters of the Labour Party that followed the line of Jaan Tonnisson at the helm of the unified centre party.

In October of 1933, the proposal put forward by the League of Veterans received overwhelming support $-72.7 \%$ of the electorate voted for substantial changes to the constitution. It appears from the results that the supporters of agrarian parties were still in favour of constitutional change, while the supporters of the Marxist parties were still opposed. The supporters of the People's Party again rejected the opinions of Jaan Tõnisson and voted en masse in favour of the proposal, as, to a lesser extent, also did the electorate of the Labour Party.

The results of the October 1933 referendum was a great success for the League of Veterans movement. It has often been claimed that this was a wholesale defeat for the established parties. This, however, is a half-truth. Agrarian parties largely kept most of their electorate, as to a significant extent did the Socialists and the Communists. In addition, the ethnic 
minorities still voted against the proposal of the League of Veterans. It was the centrists and especially the supporters of the People's Party that flocked to the League of Veterans. So even under optimistic assumptions, we believe that the Freedom Fighters might have gotten about 35\% of the vote in the parliamentary elections, which is far less than an absolute majority.

Keywords: Constitutional crisis, referendums, the League of Veterans movement, 1934 coup, linear regression.

JaAk Valge (b. 1955) is an Associate Professor at Institute of History and Archaeology at University of Tartu. ${ }^{*}$

Mark Gortfelder (b. 1991) is a Junior Researcher at Estonian Institute of Population Studies at Tallinn University.**

* Correspondence: Institute of History and Archaeology at University of Tartu, Jakobi 2, Tartu 51005, Estonia. E-mail: jaak.valge@ut.ee

** Correspondence: Estonian Institute for Population Studies, Tallinn University, Uus-Sadama 5, Room M-553, Tallinn 10120, Estonia. E-mail: mark.gortfelder@tlu.ee 